\title{
Antioxidant Characterization of Oak Extracts Combining Spectrophotometric Assays and Chemometrics
}

\author{
Boris M. Popović, ${ }^{1}$ Dubravka Štajner, ${ }^{1}$ Ružica Ždero, ${ }^{1}$ Saša Orlović, ${ }^{2}$ and Zoran Galić ${ }^{2}$ \\ ${ }^{1}$ Faculty of Agriculture, University of Novi Sad, Trg Dositeja Obradovića 8, 21000 Novi Sad, Serbia \\ ${ }^{2}$ Institute of Lowland Forestry and Environment, University of Novi Sad, Antona Čehova 13, 21000 Novi Sad, Serbia \\ Correspondence should be addressed to Boris M. Popović; popovicb@polj.uns.ac.rs
}

Received 27 August 2013; Accepted 17 September 2013

Academic Editors: N. Ercal and Z. Gao

Copyright (c) 2013 Boris M. Popović et al. This is an open access article distributed under the Creative Commons Attribution License, which permits unrestricted use, distribution, and reproduction in any medium, provided the original work is properly cited.

\begin{abstract}
Antioxidant characteristics of leaves, twigs, and acorns from two Serbian oak species Quercus robur L. and Quercus petraea L. from Vojvodina province (northern Serbia) were investigated. 80\% ethanol (in water) extracts were used for antiradical power (ARP) determinations against $\mathrm{DPPH}^{*},{ }^{\circ} \mathrm{NO}$, and $\mathrm{O}_{2}{ }^{--}$radicals, ferric reducing antioxidant power (FRAP), total phenol, tannin, flavonoid, and proanthocyanidin contents. Permanganate reducing antioxidant capacity (PRAC) was determined using water extracts. Beside, mentioned parameters, soluble proteins, lipid peroxidation (LP), pigments and proline contents were also determined. The data of different procedures were compared and analyzed by multivariate techniques (correlation matrix calculation and principal component analysis (PCA)). PCA found that investigated organs of two different oak tree species possess similar antioxidant characteristics. The superior antioxidant characteristics showed oak leaves over twigs and acorns and seem to be promising source of antioxidants with possible use in industry and pharmacy.
\end{abstract}

\section{Introduction}

Quercus trees, commonly known as oaks, belong to the family Fagaceae. They comprise 450 species worldwide [1]. European oak corresponds well with these requirements and is mainly represented by Quercus robur $\mathrm{L}$. (pedunculate) and Quercus petraea (Matt.) Liebl. (sessile oak). Oak wood is valued for its mechanical properties and durability. It has been widely used since prehistoric times [2]. Pedunculate is the dominant tree species of natural forests in the area of flat Srem and also in whole region of Vojvodina, northern Serbia. Besides pedunculate, sessile oak is the most valuable oak in Serbia [3]. In the forestry fund of Serbia, there is the significant participation of sessile oak (7.28\%) [4]. Oaks are the major source of hardwood lumber and also they are used for ornaments. The wood is durable and tough and also attractively grained. It is especially valued in shipbuilding and construction and for flooring, furniture, barrels, and veneer. The bark of some oaks has been used in medicine, in tanning, and for dyes. In mythology and religion, the oak was revered as a symbol of power [5]. In Serbia, oak is a sacred tree, used in Serbian Christmas traditions.

Acorns, the fruit of oak trees, have long been employed as a source of hog feed, tannin, oil, and especially food because of the high content of carbohydrates, amino acids, proteins, lipids, and various sterols [6, 7]. Quercus acorns were mainly used for making bread or as a substitute for coffee. Oak kernels were traditionally used in medicine, particularly roasted ones as astringents, antidiarrhoeals, and antidotes [8]. The acorns of $Q$. robur contain various biologically active compounds with antioxidant activity (tannins, gallic and ellagic acid, and different galloyl and hexahydroxydiphenoyl derivatives) $[8,9]$. It was also known that the bark of different Quercus species contains polyphenolic constituents. Thus, the bark of Q. petraea contains both hydrolysable and condensed tannins, flavanols, and oligomeric proanthocyanidins [10]. From the bark of Quercus robur more than 20 compounds (catechins and oligomeric and polymeric proanthocyanidins) have been isolated [11]. 
Polyphenols are secondary metabolites of plants that are generally involved in defense against ultraviolet radiation and pathogens. In food, polyphenols contribute to the color, flavor, odor, bitterness, astringency, and oxidative stability. Recent biomedical investigations connected to the polyphenols and antioxidant activity of a number of herbals and foods show that polyphenols such are flavonoids, tannins, and proanthocyanidins offer protection against development of cancers, cardiovascular diseases, diabetes, osteoporosis and neurodegenerative diseases $[12,13]$.

Kim et al. [14] investigated phenolic profile in leaves of five different Quercus species and approved presence of many chemical constituents. This study demonstrated differences in phenolic compounds content in different parts of plants. Quercus salicina Blume, for example, possesses high levels of gentisic and chlorogenic acids as well as flavonoids naringin and rutin in the leaf. Brossa et al. [15] established that major constituents in holm oak (Quercus ilex L.) leaves are flavanols and flavonols. According to Kamalak et al. [16], oak leaves from some Quercus species ( $Q$. branti and $Q$. libari) may have a high potential nutritive value for small ruminant animals in terms of rumen and whole tract digestion. It is established that content of phenolic compounds in Quercus species highly depends on the stage of maturity and expresses seasonal variation $[15,17]$.

Sanchez-Burgos et al. [1] established that aqueous extracts from leaves from different white Quercus species (Quercus resinosa, Quercus laeta, Quercus grisea, and Quercus obtusata) displayed high radical scavenging activity against DPPH and ${ }^{\circ} \mathrm{OH}$ radicals as well as antimicrobial activities and antitopoisomerase activity only $Q$. resinosa leaves infusions. Andrenšek et al. [18] also pointed out that Q. robur cortex is a promising plant material as the source of antioxidative and antimicrobial activity.

Bearing in mind that antioxidant potential of two major Serbian oaks Quercus robur L. and Quercus petraea L. has not been studied well enough, especially their leaves and twigs, the aim of this work was to investigate the in vitro antioxidant and scavenging activities and also total phenol (TPC), tannin (TAC), flavonoid (FLC), Proanthocyanidin (PAC), and proline contents as well as lipid peroxidation (LP) in leaves, twigs, and acorns of these two Serbian oak tree species.

\section{Materials and Methods}

2.1. Plant Material and Extraction Procedure. This paper presents antioxidant characteristics of two Serbian oak species Quercus robur L. and Quercus petraea L. from Vojvodina province, in northern Serbia. During September 2011, twigs, leaves, and acorns were picked to make average samples (from 20 trees per one replicate). Three independent replicates were made for both species. All samples were dried in open air in the dark.

After that, $20 \mathrm{~g}$ of the dried sample was finely ground into a fine powder in a mill and extracted with $500 \mathrm{~mL}$ of water for $24 \mathrm{~h}$ at $25^{\circ} \mathrm{C}$, followed by filtration. Prepared extract was used for lipid peroxidation, soluble protein, and PRAC determination. For all ARP determinations and FRAP the similar extraction tool was used, with $80 \% \mathrm{EtOH}$ (in water) as an extractant. For TPC and TAC acidic ethanol $\left(0.1 \mathrm{~mol} / \mathrm{dm}^{3}\right.$ $\mathrm{HCl}$ in $\mathrm{EtOH}$ ) was used as an extractant. For determination of $\mathrm{DPPH}^{\bullet},{ }^{\circ} \mathrm{NO}$, and $\mathrm{O}_{2}{ }^{--} \mathrm{ARP}, 80 \% \mathrm{EtOH}$ extracts were evaporated to dryness and the dry residues were redissolved again in $80 \% \mathrm{EtOH}$ (in water) to obtain mass concentration $25 \mathrm{mg} / \mathrm{mL}$ (for $\mathrm{DPPH}^{\bullet},{ }^{\bullet} \mathrm{NO}$ and $\mathrm{O}_{2}{ }^{\cdot-}$ ARP determination).

2.2. Lipid Peroxidation, Proline, Soluble Protein, and Pigment Contents. Lipid peroxidation (LP) was estimated based on thiobarbituric acid (TBA) reactivity. Samples were evaluated for malondialdehyde (MDA) production using a spectrophotometric assay. The extinction coefficient of $153,000 \mathrm{~mol}^{-1} \mathrm{~cm}^{-1}$ at $532 \mathrm{~nm}$ for the chromophore was used to calculate the colour intensity of the MDA-TBA complex in the supernatant [19].

Proline accumulation was determined by the method as described by Paquin and Lechasseur [20]. Proline was determined after extraction with sulphosalicylic acid, and reaction with ninhydrin. A standard curve of proline was used for calibration and was measured by its absorbance at $532 \mathrm{~nm}$.

Pigments were extracted with acetone and determined spectrophotometrically using molar extinction coefficients according to von Wettstein [21]. Soluble protein content was determined by the method of Bradford [22].

2.3. Total Phenol, Tannin, Flavonoid, and Proanthocyanidin Contents. Total polyphenols were determined by FolinCiocalteu procedure [23]. The amount of total polyphenols was calculated as a catechin equivalent from the calibration curve of catechin standard solutions (covering the concentration range between 0.1 and $1.0 \mathrm{mg} / \mathrm{mL}$ ) and expressed as $\mathrm{mg}$ catechi/100 g dry plant material.

Total tannin content was determined by Folin-Ciocalteu procedure as above, after removal of tannins by their adsorption on insoluble matrix (polyvinylpolypyrrolidone, PVPP). Calculated values were subtracted from total polyphenol contents and total tannin contents expressed as mg catechine/100 g dry plant material.

Total flavonoids were determined after extraction of plant material (1 g) with extracting solvent methanol-water-acetic acid (140:50:10, V/V), according to Markham [24]. The amount of flavonoids was calculated as a rutin equivalent from the calibration curve of rutin standard solutions and expressed as mg rutin/100 $\mathrm{g}$ of plant material.

Proanthocyanidins were determined by butanol- $\mathrm{HCl}$ assay [23]. Their contents were expressed as mg leucoanthocyanidin/100 $\mathrm{g}$ of dry plant material, assuming that the specific absorbance of leucoanthocyanidin was 460 .

All measurements were done in triplicate.

2.4. FRAP. Total antioxidant capacity was estimated according to the ferric reducing antioxidant power (FRAP) assay [25]. FRAP reagent was prepared by mixing acetate buffer (300 mM pH 3.6), TPTZ (2,4,6-tripyridyl-s-triazine) reagent $(10 \mathrm{mM}$ in $40 \mathrm{mM} \mathrm{HCl})$, and $\mathrm{FeCl}_{3} \cdot 6 \mathrm{H}_{2} \mathrm{O}(20 \mathrm{mM})$ in ratio 
$3: 1: 1$. Sample $(100 \mu \mathrm{L})$ was mixed with $3 \mathrm{~mL}$ of working FRAP reagent and absorbance $(593 \mathrm{~nm})$ was measured at 4 minutes after vortexing. FRAP value was calculated using formula

$$
\text { FRAP value }=\frac{\Delta A_{\text {sample }}(0-4 \mathrm{~min})}{\Delta A_{\text {standard }}(0-4 \mathrm{~min})} .
$$

$100 \mu \mathrm{M} \mathrm{Fe}^{2+}$ was used as a standard; 1 FRAP unit $=100 \mu \mathrm{M}$ $\mathrm{Fe}^{2+}$.

Total antioxidant capacity was expressed in FRAP units.

2.5. Permanganate Reducing Antioxidant Capacity. The method is based on the redox reactions between the antioxidant sample and the potassium permanganate in sulfuric acid media, leading to sample discoloration until no colour is observed [26]. Variable amounts of samples $(V-\mathrm{mL})$, depending on the intensity of the antioxidant activity, were introduced in a $30 \mathrm{~mL}$ quartz vat containing an oxidative mixture of $1.5 \mathrm{~mL}$ potassium permanganate $0.01 \mathrm{M} ; 3.5 \mathrm{~mL}$ sulfuric acid $2 \mathrm{M}$, and $(20-V) \mathrm{mL}$ distilled water. That moment was considered the zero time. The spectrophotometer signal was then registered at $535 \mathrm{~nm}$ until constant value. Subsequent decrease of potassium permanganate concentration was determined based on a previously prepared calibration curve. A calibration curve was determined by preparing a series of six solutions with different concentrations of potassium permanganate and registering the absorbance for each of them. In order to quantitatively compare the antioxidant activities, we proposed the following formula:

$$
A_{50}=\frac{t_{\text {(standard) }}}{t_{\text {(plant sample) }}} \cdot \frac{c_{\text {(standard) }}}{m_{\text {(plant) }}} \cdot \frac{V_{\text {(standard) }}}{V_{\text {(plant sample) }}} \cdot V_{\text {(extract) }},
$$

where $A_{50}$ is antioxidant activity expressed, reflected in the time until the sample induces a decrease of the oxidizing agent [potassium permanganate] concentration up to one half, compared against a standard [ascorbic acid] (mmol equivalent standard/g plant), $t_{\text {(plant sample) }}$ is the time until the sample induces a decrease of the permanganate concentration up to one half (min), $t_{\text {(standard) }}$ is the time until the standard (ascorbic acid) induces a decrease of the permanganate concentration up to one half (min), $c_{\text {(standard) }}$ is standard (ascorbic acid) concentration $(\mathrm{mmol} / \mathrm{mL})[0.01 \mathrm{mmol} / \mathrm{mL}]$, $m_{\text {(plant) }}$ is weight $(\mathrm{g})$ of the plant sample submitted to extraction [4 $\mathrm{g}], V_{\text {(plant sample) }}$ is volume of the plant extract submitted to the analysis $[0.2 \mathrm{~mL}], V_{\text {(standard) }}$ is volume of the standard submitted to the analysis [1 $1 \mathrm{~mL}]$, and $V_{\text {(extract) }}$ is volume $(\mathrm{mL})$ of the obtained extract $[40 \mathrm{~mL}]$.

2.6. Radical Scavenging Determinations. DPPH'-RSC assay was based on measurement of the loss of DPPH (2,2diphenyl-1-picrylhydrazyl) color after reaction with test compounds [27]. The $\mathrm{DPPH}^{*}$ radical is one of the few stable organic nitrogen radicals, which bears a deep purple color. This assay is based on the measurement of the reducing ability of antioxidants toward $\mathrm{DPPH}^{*}$. The ability can be evaluated by measuring the decrease of its absorbance. The widely used decoloration assay was first reported by Brand-Williams et al. [28]. Appropriate volume of each extract was mixed with $90 \mu \mathrm{M} \mathrm{DPPH}^{*}$ in methanol making up final volume of $3.0 \mathrm{~mL}$. The mixtures were shaken vigorously and were stored in dark for $30 \mathrm{~min}$ at room temperature. The decrease of absorbance of the reaction mixtures regarding the control was monitored spectrophotometrically at $515 \mathrm{~nm}$.

"NO-RSC was evaluated by measuring the accumulation of nitrite (formed by the reaction of NO with oxygen), according to the Griess reaction [29]. NO was generated by sodium nitroprusside in buffered aqueous solution. Appropriate volume of each extract was mixed with fresh prepared solution of sodium nitroprusside $(0.5 \mathrm{~mL}, 0.01 \mathrm{M}$ in $\mathrm{NaH}_{2} \mathrm{PO}_{4}-\mathrm{Na}_{2} \mathrm{HPO}_{4}$ buffer, $0.067 \mathrm{M}$, pH 7.4) and $\mathrm{NaH}_{2} \mathrm{PO}_{4}-$ $\mathrm{Na}_{2} \mathrm{HPO}_{4}$ buffer $(0.067 \mathrm{M}$, pH 7.4) making final volume of $1.0 \mathrm{~mL}$. These mixtures were illuminated at $3000 \mathrm{~lx}$ and $25^{\circ} \mathrm{C}$ for $10 \mathrm{~min}$. After illumination, each reaction mixture $(1 \mathrm{~mL})$ was mixed with Griess reagent $(1 \mathrm{~mL}, 0.1 \% \mathrm{~N}$-(1-naphtyl)ethylenediamine dihydrochloride (NEDA) in distilled water and $1 \%$ sulfanilamide in $5 \% \mathrm{H}_{3} \mathrm{PO}_{4}$ ). Reduction of nitrite by the extracts was determined spectrophotometrically at $546 \mathrm{~nm}$, by measuring the decrease of absorbance of the reaction mixtures regarding the control (containing the same chemicals, except for the sample).

$\mathrm{O}_{2}{ }^{--}$-RSC assay was based on the capacity of crude extracts to inhibit the photochemical reduction of nitro blue tetrazolium (NBT) in the riboflavin-light-NBT system [30]. Each $3 \mathrm{~mL}$ of reaction mixture contained sodium phosphate buffer $(50 \mathrm{mM}, \mathrm{pH} 7.8)$, methionine $(13 \mathrm{mM})$, riboflavin $(2 \mu \mathrm{M})$, EDTA $(100 \mu \mathrm{M})$, NBT $(75 \mu \mathrm{M})$, and extract solution. Reaction systems were illuminated at $3000 \mathrm{~lx}$ and $25^{\circ} \mathrm{C}$ for $10 \mathrm{~min}$. The increase in absorbance at $560 \mathrm{~nm}$ was monitored. The scavenging capacity was expressed as reduction percentage of NBT absorbance induced by sample.

For each sample three replicates were carried out. RSC was calculated by the following equation:

$$
\mathrm{RSC}=\left(\frac{A_{0}-A_{1}}{A_{0}}\right) \cdot 100,
$$

where $A_{0}$ is control and $A_{1}$ is a sample solution absorbance. The concentration (in the final reaction media in each method) that causes a decrease in the initial absorbance (control) by $50 \%$ is defined as $\mathrm{IC}_{50}$. The $\mathrm{IC}_{50}$ values for all RSC determinations were determined by polynomial fitting of the inhibition values (RSC) using software ORIGIN 9.1. The antioxidant capacity of the extracts was expressed as antiradical power (ARP) and it was defined as

$$
\mathrm{ARP}=\left(\frac{1}{\mathrm{IC}_{50}}\right) \cdot 100
$$

2.7. Statistical and PCA Analysis. Statistical comparisons between samples were performed with Duncan $t$-test for independent observations. Differences were considered significant at $P<0.05$. The antioxidant test results were investigated with multivariate analysis. The correlation matrix was calculated, giving the correlation coefficients between each pair of variables, that is, the analytical parameters tested. 
Each term of the matrix is a number ranging from -1 to +1 : the + or - sign indicates a positive or negative interdependence between variables (direction), and the absolute value indicates the strength of the interdependence. Correlations between different parameters were considered significant at $r>0.95(P<0.05)$. Autoscaling transformation of data for phenolic parameters (TPC, TAC, FLC, and PAC) was done using STATISTICA 9.1 and presented by graphic (Figure 2).

\section{Results and Discussion}

3.1. Soluble Proteins, Proline, Pigment and MDA Contents. Soluble protein content ranged from 52.45 (Q. robur twigs) to $427.0 \mathrm{mg} / \mathrm{g}$ (Q. robur leaves); Proline content ranged from 0.041 (Q. petraea acorns) to $0.083 \mu \mathrm{g} / \mathrm{g}$ (Q. robur twigs); Chla content ranged from 0.016 (Q. robur acorns) to $0.229 \mathrm{mg} / \mathrm{g}$ (Q. petraea leaves); Chlb content ranged from 0.017 (Q. robur acorns) to $0.164 \mathrm{mg} / \mathrm{g}$ (Q. petraea leaves); Carotenoid content ranged from 0.009 (Q. robur acorns) to $0.175 \mathrm{mg} / \mathrm{g}$ (Q. robur leaves); MDA content ranged from 2.023 (Q. petraea acorns) to $67.18 \mathrm{nmol} / \mathrm{mg}$ protein (Q. robur twigs), (Tables 1 and 2). Significant positive correlations were found between Chla and Chlb $(r=0.9957)$, and also between carotenoids and both chlorophylls $(r=0.84)$. Positive correlation was found between proline content and MDA content $(r=0.4459)$.

Lipids are susceptible to oxidation and lipid peroxidation products, such as MDA quantity, are potential biomarkers for oxidative stress status in vivo. Proteins are also the direct target for Reactive Oxygen Species (ROS) because of their high concentrations. Their oxidation may result in deamination, decarboxylation, peptide backbone cleavage, cross-linking, and many other chemical modifications leading eventually to inactivation of enzyme activity and accumulation within cells and extracellular environment [31]. Furthermore, antioxidant capacity and the ratio between reduced forms to oxidized forms of molecules may be also used as biomarkers of oxidative stress [32]. According to our results, the highest accumulation of MDA was observed in twigs of both Quercus species, where the soluble protein content was lowest due to increased level of oxidative stress.

Carotenoids, along with phenolics, are responsible for bright colours of plants and are also powerful antioxidants. Carotenoids can protect membranes against damage by free radicals and retard the ageing processes [33]. The highest content of pigments, carotenoids, and chlorophylls was found in the leaves of both, especially Q. petraea. Proline is an amino acid that acts as an antioxidant-it reduces free radicals in plant cells $[34,35]$. Its production is a self-defense mechanism. Plant's proline levels are an indicator of both the environment stress and the plant's response. Proline does not interfere with normal biochemical reactions but allows the plants to survive under stress [36]. The accumulation of proline in plant tissues is also a clear marker for environmental stress, particularly in plants under drought conditions and may also be part of the stress signal influencing adaptive responses [37]. Positive correlation between free proline content and LP intensity confirms both antioxidant and defense natures of this amino acid.
3.2. Total Phenol, Tannin, Flavonoid, and Proanthocyanidin Contents. Total phenol content ranged from 7.44 ( $Q$. petraea twigs) to $35.52 \mathrm{mg}$ catechin/g (Q. petraea leaves); Tannin content ranged from 4.667 (Q. petraea twigs) to $26.24 \mathrm{mg}$ catechin/g (Q. petraea leaves); Flavonoid content ranged from 19.12 (Q. petraea twigs) to $306.1 \mathrm{mg}$ rutin $/ 100 \mathrm{~g}$ (Q. petraea leaves); Proanthocyanidine content ranged from 79.04 (Q. petraea twigs) to $1102 \mathrm{mg}$ rutin/100 g ( $Q$. robur leaves) (Table 1). Significant positive correlations were observed between all mentioned parameters. The highest positive correlation was observed between TPC and TAC $(r=0.9955)$. All phenolic parameters were significantly positively correlated with carotenoid content. Total phenol, tannin, and flavonoid contents were also significantly positively correlated with both chlorophylls (a and b). Phenolic parameters were analyzed by a multivariate approach and results are showed by line plot of multiple variables (Figure 3 ). All phenolic parameters are negatively but not significantly correlated with LP parameter.

Our results are in accordance with that obtained by Rakić et al. [38] who indicated that oak acorns from $Q$. robur are material rich in polyphenols and tannins. We have found similar results for Q. petraea acorns. Kamalak et al. [16] evaluated nutritive values of browse leaves from five oak species, namely, Quercus branti, Quercus coccifera, Quercus cerris, Quercus libari, and Quercus infectoria based on their chemical composition. It was established that tannin content ranged from 14.9 to $47.9 \mathrm{mg} / \mathrm{g}$ matter which is in accordance with our results for $Q$. robur and $Q$. petraea. $Q$. petraea and $Q$. robur are also rich source of flavonoids and proanthocyanidins which are found in all plant organs, especially in leaves. Flavonoid content found in leaves of $Q$. petraea and $Q$. robur is in range of that found in Quercus salicina Blume [39]. According to Salminen et al. (2004) hydrolysable tannins were the dominant phenolic group in leaves of all ages of $Q$. robur which is in well agreement with our results. However, hydrolysable tannins and flavonoid glycosides showed highly variable seasonal patterns. Young oak leaves were much richer in hydrolysable tannins and flavonoid glycosides than old leaves, and vice versa for proanthocyanidins [40]. Although in smaller quantities, twigs also contained all classes of polyphenols (Table 1). The obtained results have provided further grounds for establishing $Q$. robur and Q. petraea leaves, acorns, and twigs as a source for functional food preparation.

3.3. FRAP and PRAC Methods. FRAP values ranged from 141.54 (Q. robur twigs) to 1252.3 FRAP units (Q. petraea leaves); PRAC values ranged from 0.010 (Q. petraea twigs) to $0.543 \mathrm{mmol}$ ascorbate eq./g (Q. petraea acorns) (Table 2). FRAP was significantly positively correlated with phenolic parameters (TPC, TAC, and FLC) and with pigment (Chla, $\mathrm{Chlb}$, and Car) contents. The highest positive correlation was observed between FRAP and TAC $(r=0.9587)$. PRAC value was positively correlated with $\mathrm{O}_{2}{ }^{--}$-ARP $(r=0.6196)$ and negatively correlated with LP $(r=-0.8113)$.

Benzie and Strain [25] introduced FRAP as a simple and automated test measuring the ferric reducing ability 
TABLE 1: Total phenol, tannin, flavonoid, proantocyanidine, chlorophyll a and b, carotenoid, and proline contents in oak twigs, leaves, and acorns of two Serbian oak species Quercus robur L. and Quercus petraea L.

\begin{tabular}{lccccccccc}
\hline Plant organ & Locality & $\begin{array}{c}\text { TPC } \\
(\text { mg catechin/g) }\end{array}$ & $\begin{array}{c}\text { TAC } \\
(\text { mg catechin/g) }\end{array}$ & $\begin{array}{c}\text { FLC } \\
(\text { mg rutin/100 g) }\end{array}$ & $\begin{array}{c}\text { PAC } \\
(\text { mg leukocyani- } \\
\text { dine/100 g) }\end{array}$ & $\begin{array}{c}\text { Chla } \\
(\mathrm{mg} / \mathrm{g})\end{array}$ & $\begin{array}{c}\text { Chlb } \\
(\mathrm{mg} / \mathrm{g})\end{array}$ & $\begin{array}{c}\text { Car } \\
(\mathrm{mg} / \mathrm{g})\end{array}$ & $\begin{array}{c}\text { Pro. } \\
(\mu \mathrm{g} / \mathrm{g})\end{array}$ \\
\hline \multirow{2}{*}{ Twigs } & Q. robur & $12.86^{\mathrm{a}}$ & $9.094^{\mathrm{a}}$ & $22.06^{\mathrm{a}}$ & $148.9^{\mathrm{a}}$ & $0.033^{\mathrm{a}}$ & $0.027^{\mathrm{a}}$ & $0.029^{\mathrm{a}}$ & $0.083^{\mathrm{a}}$ \\
& Q. petraea & $7.44^{\mathrm{b}}$ & $4.667^{\mathrm{b}}$ & $19.12^{\mathrm{a}}$ & $79.04^{\mathrm{b}}$ & $0.035^{\mathrm{a}}$ & $0.042^{\mathrm{b}}$ & $0.018^{\mathrm{b}}$ & $0.053^{\mathrm{b}}$ \\
\multirow{2}{*}{ Leaves } & Q. robur & $32.37^{\mathrm{c}}$ & $22.47^{\mathrm{c}}$ & $290.2^{\mathrm{b}}$ & $1102^{\mathrm{c}}$ & $0.115^{\mathrm{b}}$ & $0.091^{\mathrm{c}}$ & $0.175^{\mathrm{c}}$ & $0.067^{\mathrm{c}}$ \\
& Q. petraea & $35.52^{\mathrm{d}}$ & $26.24^{\mathrm{d}}$ & $306.1^{\mathrm{c}}$ & $757.6^{\mathrm{d}}$ & $0.229^{\mathrm{c}}$ & $0.164^{\mathrm{d}}$ & $0.147^{\mathrm{d}}$ & $0.075^{\mathrm{d}}$ \\
\multirow{2}{*}{ Acorns } & Q. robur & $16.25^{\mathrm{e}}$ & $11.76^{\mathrm{e}}$ & $26.17^{\mathrm{a}}$ & $612.4^{\mathrm{e}}$ & $0.016^{\mathrm{d}}$ & $0.017^{\mathrm{e}}$ & $0.009^{\mathrm{e}}$ & $0.077^{\mathrm{ad}}$ \\
& Q. petraea & $15.90^{\mathrm{e}}$ & $12.65^{\mathrm{e}}$ & $73.81^{\mathrm{d}}$ & $163.6^{\mathrm{a}}$ & $0.026^{\mathrm{a}}$ & $0.032^{\mathrm{a}}$ & $0.023^{\mathrm{ab}}$ & $0.041^{\mathrm{e}}$ \\
\hline
\end{tabular}

*Values with the same letter, in each colon, are not significantly different according to Duncan test $(P<0.05)$.

${ }^{* *}$ TPC: total phenolic content; TAC: tannin content; FLC: flavonoid content; PAC: proanthocyanidin content; Chla and Chlb: chlorophyll a and b contents; Car: carotenoid content; Pro: proline content.

TABLE 2: Protein content, DPPH, NO, and $\mathrm{O}_{2}{ }^{--}$-antiradical powers, permanganate reducing antioxidant capacity, ferric reducing antioxidant power, and lipid peroxidation in oak twigs, leaves, and acorns of two Serbian oak species Quercus robur L. and Quercus petraea L.

\begin{tabular}{|c|c|c|c|c|c|c|c|c|}
\hline $\begin{array}{l}\text { Plant } \\
\text { organ }\end{array}$ & Locality & $\begin{array}{c}\text { Prot. } \\
\text { (mg/g) }\end{array}$ & $\begin{array}{c}\text { DPPH-ARP } \\
\left(\left(1 / \mathrm{IC}_{50}\right) \cdot 100\right)\end{array}$ & $\begin{array}{c}\text { NO-ARP } \\
\left(\left(1 / \mathrm{IC}_{50}\right) \cdot 100\right)\end{array}$ & $\begin{array}{c}\mathrm{O}_{2}{ }^{--}-\mathrm{ARP} \\
\left(\left(1 / \mathrm{IC}_{50}\right) \cdot 100\right)\end{array}$ & $\begin{array}{c}\text { PRAC } \\
\left(\mathrm{A}_{50}\right)\end{array}$ & $\begin{array}{l}\text { FRAP (FRAP } \\
\text { units) }\end{array}$ & $\begin{array}{c}\text { LP } \\
\text { (nmol/mg prot.) }\end{array}$ \\
\hline \multirow{2}{*}{ Twigs } & Q. robur & $52.45^{\mathrm{a}}$ & $5.874^{\mathrm{a}}$ & $0.358^{\mathrm{a}}$ & $2.174^{\mathrm{a}}$ & $0.016^{\mathrm{a}}$ & $141.54^{\mathrm{a}}$ & $67.18^{\mathrm{a}}$ \\
\hline & Q.petraea & $103.9^{\mathrm{b}}$ & $4.039^{\mathrm{b}}$ & $0.241^{\mathrm{b}}$ & $3.571^{b}$ & $0.010^{\mathrm{a}}$ & $178.5^{\mathrm{a}}$ & $28.08^{\mathrm{b}}$ \\
\hline \multirow{2}{*}{ Leaves } & Q. robur & $427.0^{c}$ & $7.628^{c}$ & $0.531^{\mathrm{c}}$ & $3.448^{\mathrm{b}}$ & $0.304^{\mathrm{b}}$ & $873.8^{\mathrm{b}}$ & $11.01^{c}$ \\
\hline & Q. petraea & $159.6^{\mathrm{d}}$ & $8.779^{\mathrm{d}}$ & $0.400^{\mathrm{d}}$ & $4.785^{\mathrm{c}}$ & $0.235^{\mathrm{c}}$ & $1252.3^{\mathrm{c}}$ & $11.96^{\mathrm{c}}$ \\
\hline \multirow{2}{*}{ Acorns } & Q. robur & $352.1^{\mathrm{e}}$ & $9.066^{\mathrm{d}}$ & $0.188^{\mathrm{e}}$ & $5.359^{\mathrm{d}}$ & $0.411^{\mathrm{d}}$ & $370.0^{\mathrm{d}}$ & $3.282^{\mathrm{d}}$ \\
\hline & Q.petraea & $95.60^{\mathrm{b}}$ & $6.734^{\mathrm{e}}$ & $0.202^{\mathrm{e}}$ & $4.098^{\mathrm{e}}$ & $0.543^{\mathrm{e}}$ & $614.6^{\mathrm{e}}$ & $2.023^{\mathrm{d}}$ \\
\hline
\end{tabular}

${ }^{*}$ Values with the same letter, in each colon, are not significantly different according to Duncan test $(P<0.05)$.

** Prot.: proteins; ARP: antiradical power; $\mathrm{ARP}=\left(\left(1 / \mathrm{IC}_{50}\right) \cdot 100\right) ; \mathrm{IC}_{50}$ : the concentration of an sample at which $50 \%$ inhibition of free radical activity is observed; PRAC: permanganate reducing antioxidant capacity; $\mathrm{A}_{50}$ : antioxidant activity reflected in time until the sample induces a decrease of the oxidizing agent (potassium permanganate) up to one half, compared against a standard (ascorbic acid); $\mathrm{A}_{50}=$ mmol ascorbate eq./g; FRAP: ferric reducing antioxidant power; 1 FRAP unit $=100 \mu \mathrm{mol} / \mathrm{dm}^{3} \mathrm{Fe}^{2+} ; \mathrm{LP}$ : lipid peroxidation.

of plasma and a novel method for assessing "antioxidant power." Ferric to ferrous ion reduction at low $\mathrm{pH}$ causes a colored ferrous-tripyridyltriazine complex to form. According to Maqsood and Benjakul [41] tannic acid showed higher FRAP value in comparison with other investigated phenolics including catechin which is in agreement with our observation that the highest positive correlation was found between FRAP and TAC parameter. Same reaction mechanism based on electron transfer explains high positive correlations between FRAP and phenolic parameters (TPC, TAC, and FLC) [42]. According to FRAP method, antioxidant capacity of oak samples, especially leaves, was relatively high comparing with other plants [43-45]. FRAP value was more or less positively correlated with all investigated parameters excluding LP, where negative correlation was found (-0.5448).

PRAC method was firstly introduced by Cacig and Szabo [26] as a simple spectrophotometric method for evaluation of antioxidant capacity and later compared with other total antioxidant capacity methods [46]. Unlike the oak leaves where the highest FRAP was found, oak acorns showed the highest PRAC. High positive correlations with $\mathrm{O}_{2}{ }^{--}$-ARP indicate that the same structures are probably responsible for superoxide scavenging and for reduction of permanganate in acidic media. The highest negative correlations of both parameters with LP also indicate that scavengers of superoxide and substances with high reducing potential against permanganate are mostly responsible for suppression of LP.

3.4. Antiradical Power Determinations. DPPH-ARP ranged from 4.039 (Q. petraea twigs) to 9.066 (Q. robur acorns); NOARP ranged from 0.188 (Q. robur acorns) to 0.531 (Q. robur leaves); $\mathrm{O}_{2}{ }^{--}$-ARP ranged from 2.174 (Q. robur twigs) to 5.359 (Q. robur acorns) (Table 2 ). DPPH-ARP and NO-ARP were positively correlated with all phenolic parameters (TPC, TAC, FLC, and PAC), pigments (Chla, Chlb, and Car), and FRAP. In contrast to them, $\mathrm{O}_{2}{ }^{--}$-ARP showed rather less positive correlations with phenolic parameters, pigments, and FRAP but relatively high positive correlation with PRAC (0.6196). Among investigated ARP parameters, only $\mathrm{O}_{2}{ }^{--}$-ARP showed significant negative correlation with $\mathrm{LP}(r=-0.8360)$.

All three ARP power determinations against DPPH, $\mathrm{O}_{2}{ }^{--}$, and NO radicals generally proceed also via hydrogen atom transfer or electron transfer mechanism depending on present antioxidant structure, $\mathrm{pH}$, dielectric constant of the solvent, and so forth [46]. DPPH and $\mathrm{O}_{2}{ }^{--}$-ARP were correlated with each other $(r=0.6776)$, while correlations with NO-ARP were much lower. Significant positive correlation of 


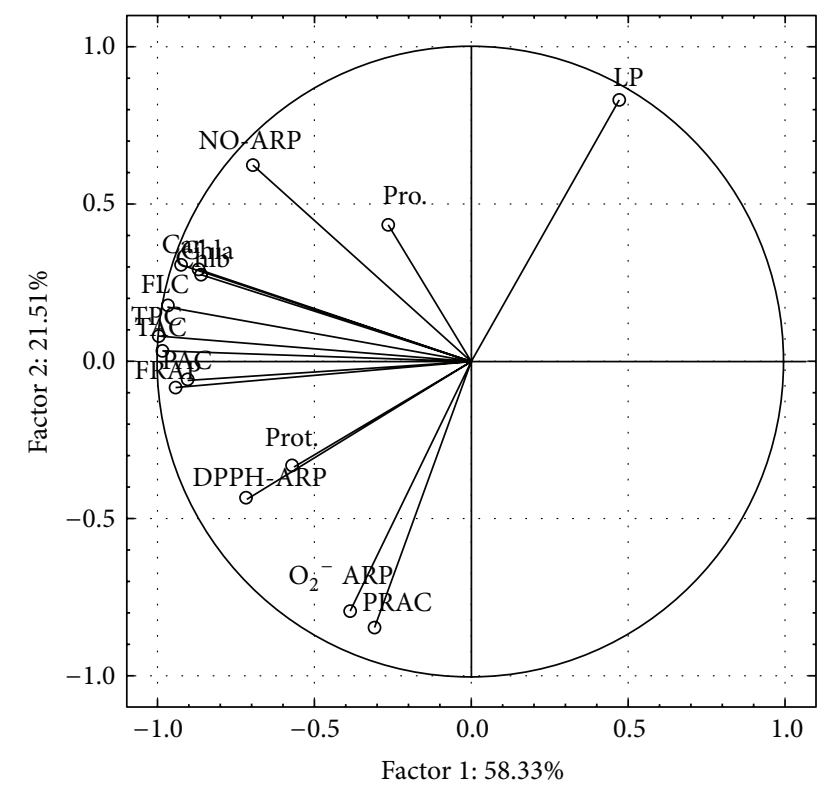

FIGURE 1: Graph of loading plot of antioxidant markers for Serbian oak species Quercus robur L. and Quercus petraea L. Prot.: proteins; ARP: antiradical power; PRAC: permanganate reducing antioxidant capacity; FRAP: ferric reducing antioxidant power; LP: lipid peroxidation; TPC: total phenolic content; TAC: tannin content; FLC: flavonoid content; PAC: Proanthocyanidin content. Chla and Chlb: chlorophyll a and b contents; car: Carotenoid content; Pro: proline content. Parameters with close interdependence and correlation are close to each other and vice versa.

NO-ARP and carotenoids ( $r=0.8525)$ indicated significance of carotenoid antioxidants for NO scavenging. Sindhu et al. [47] also established that carotenoids lutein and zeaxanthin showed stronger antiradical potential against $\mathrm{NO}$ than $\mathrm{DPPH}$ and $\mathrm{O}_{2}{ }^{--}$radicals. The highest DPPH- and $\mathrm{O}_{2}{ }^{--}$-ARP showed acorns and the highest NO-ARP showed leaves Q. robur. Rivas-Arreola et al. [48] also investigated antioxidant activity of oak (Q. sideroxyla, Q. Eduardii, and Q. resinosa) leaves infusions against free radicals and obtained similar results for radical scavenger capacities. Oak twigs expressed lower DPPH, $\mathrm{O}_{2}{ }^{--}$, and NO ARP in comparison with leaves and acorns but also relatively high antiradical potential.

3.5. PCA Analysis. The original data set was renormalized by an autoscaling transformation (data not shown) and different parameters were analyzed by a multivariate approach. The loadings plot is presented by Figure 1 and the scores plot by Figure 2. The scree plot (data not shown) indicates that the first two principal components account for $79.84 \%$ of the total variance $(\mathrm{PC1}=58.33$ and $\mathrm{PC} 2=21.51)$.

As reported in the loadings plot (Figure 1), antiradical power parameters $\left(\mathrm{DPPH}^{\circ},{ }^{-} \mathrm{NO}\right.$, and $\mathrm{O}_{2}{ }^{--}$-ARP), FRAP, polyphenol (TPC, TAC, FLC, and PAC), protein, and pigment contents are positioned closely due to the significant positive correlations among them. PRAC and $\mathrm{O}_{2}{ }^{--}$ARP are partially isolated and located opposite to LP as a parameter of oxidative stress. Positive correlations were also found among

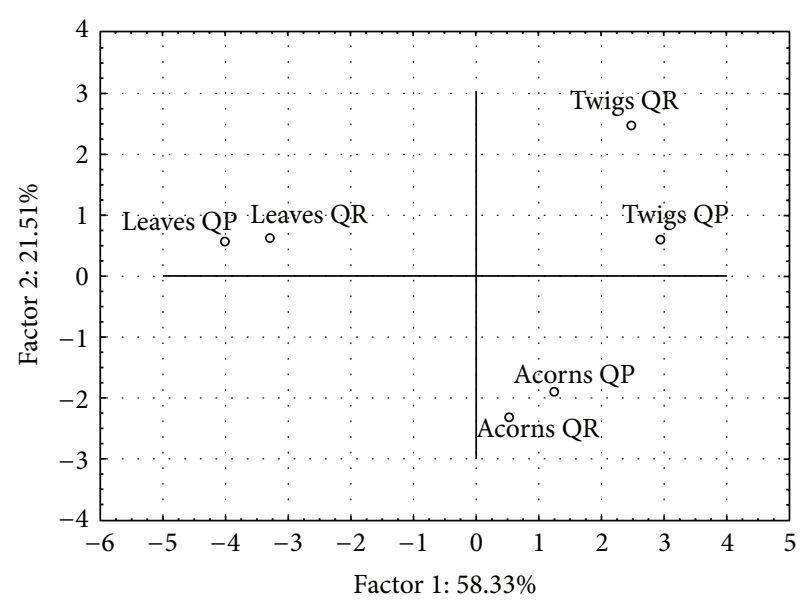

FIGURE 2: Graph of scores plot for Serbian oak species Quercus robur $\mathrm{L} .(\mathrm{QR})$ and Quercus petraea L. (QP). Quercus robur L. (QR) and Quercus samples that are close to each other possess similar antioxidant statuses.

DPPH-ARP and proteins and also between ${ }^{\circ} \mathrm{NO}-\mathrm{ARP}$ and proline content.

PCA found three different clusters of oak samples based on antioxidant characteristics: leaves, acorns, and twigs from investigated species are grouped (Figure 2). Leaves differ from twigs and acorns predominantly by Factor 1 (where the major contributors are polyphenols and FRAP). And the difference between twigs and acorns is based on Factor 2 (where the major contributors are LP, PRAC, and $\mathrm{O}_{2}{ }^{--}$-ARP). Opposite direction of LP on one side and PRAC $\mathrm{O}_{2}{ }^{--}$-ARP on another side indicates that the major contributors against lipid peroxidation are components which are antioxidants which can easily reduce permanganate and also scavenge $\mathrm{O}_{2}{ }^{--}$-radicals. Very close interdependence was observed between leaves and twigs from both species, but twigs from two Quercus species showed slightly higher differences. Line plot of multiple variables after autoscaling transformation of polyphenolic content parameters (TPC, TAC, FLC, and PAC) was shown in Figure 3. It is obvious that polyphenolic parameters for leaves are separated and are greater than the same parameters for acorns and twigs.

\section{Conclusion}

This investigation pointed out antioxidant potential of both Serbian oak species (Q. robur and Q. petraea). Leaves from both oak species possessed high contents of total phenols, tannins, flavonoids, proanthocyanidins, and pigment contents. Antiradical power parameters were also very high for oak leaves and LP intensity was relatively low. Ferric reducing antioxidant capacity was the highest in oak leaf extracts, especially for Q. petraea. Among investigated leaf extracts which are significant source of phenolic compounds, oak acorns showed also high antioxidant potential and the lowest LP intensity. Antioxidant capacity values including $\mathrm{DPPH}^{\circ}$, 'NO and $\mathrm{O}_{2}{ }^{--}$-ARP, and FRAP showed high positive correlations among themselves and also with polyphenol parameters 


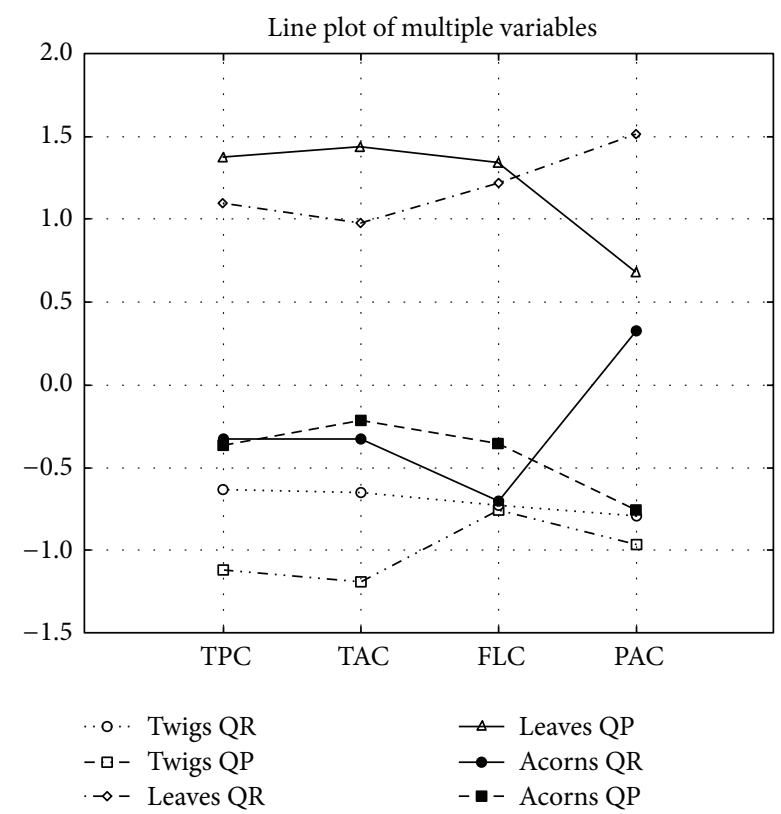

FIGURE 3: Line plot of multiple variables after autoscaling transformation of phenolic content parameters (TPC, TAC, FLC, and PAC). Quercus robur L. (QR) and Quercus petraea L. (QP). TPC: Total phenolic content; TAC: Tannin content; FLC: Flavonoid content; PAC: Proanthocyanidin content.

(TPC, TAC, FLC, and PAC), protein, and pigment contents. Permanganate PRAC and $\mathrm{O}_{2}{ }^{--}$-ARP were selected as the best antioxidant markers for oak trees because of the highest negative correlations with LP intensity. Considering high antioxidant potential of investigated organs of Serbian oak species (Q. robur and Q. petraea), besides acorns, oak leaves, and even twigs, could be recommended as source of natural antioxidants and promising source of pharmaceuticals with possible use in industry and pharmacy.

$\begin{array}{ll}\text { Abbreviations } \\ \text { PCA: } & \text { Principal component analysis } \\ \text { RSC: } & \text { Radical scavenging capacity } \\ \text { ARP: } & \text { Antiradical power } \\ \text { PRAC: } & \text { Permanganate reducing antioxidant } \\ & \text { capacity } \\ \text { FRAP: } & \text { Ferric reducing antioxidant power } \\ \text { LP: } & \text { Lipid peroxidation } \\ \text { TPC: } & \text { Total phenolic content } \\ \text { TAC: } & \text { Tannin content } \\ \text { FLC: } & \text { Flavonoid content } \\ \text { PAC: } & \text { Proanthocyanidin content } \\ \text { Chla and Chlb: } & \text { Chlorophyll a and b contents } \\ \text { Car: } & \text { Carotenoid content } \\ \text { Pro: } & \text { Proline content. }\end{array}$

\section{Acknowledgment}

This research is part of Project no. III43002 which is financially supported by the Ministry of Science, Technologies and Development of the Republic of Serbia.

\section{References}

[1] J. A. Sanchez-Burgos, M. V. Ramirez-Maresb, M. M. Larrosac et al., "Antioxidant, antimicrobial, antitopoisomerase and gastroprotective effect of herbal infusions from four Quercus species," Industrial Crops and Products, vol. 42, pp. 57-62, 2013.

[2] K. Haneca, K. C. Katarina Čufar, and H. Beeckman, "Oaks, tree-rings and wooden cultural heritage: a review of the main characteristics and applications of oak dendrochronology in Europe," Journal of Archaeological Science, vol. 36, no. 1, pp. 1-11, 2009.

[3] R. Cvjetićanin, R. O. Košanin, and M. Novaković, "Ekološke jedinice šuma hrasta kitnjakau istraživanim sastojinama severoistočne Srbije," Šumarstvo, vol. 3, pp. 25-36, 2005.

[4] M. Knežević, V. Babić, Z. Galić, and O. Košanin, "Osobine zemljišta u šumama hrasta kitnjaka (Quercetum montanum typicum Čer. et Jov. 1953) na području Fruške gore," Glasnik Sumarskog Fakulteta, vol. 104, pp. 97-108, 2011.

[5] http://www.about-oak-trees.com/index2.htm.

[6] I. M. G. Lopes and M. G. Bernardo-Gil, "Characterisation of acorn oils extracted by hexane and by supercritical carbon dioxide," European Journal of Lipid Science and Technology, vol. 107, no. 1, pp. 12-19, 2005.

[7] M. León-Camacho, I. Viera-Alcaide, and I. M. Vicario, "Acorn (Quercus spp.) fruit lipids: saponifiable and unsaponifiable fractions: a detailed study," Journal of the American Oil Chemists' Society, vol. 81, no. 5, pp. 447-453, 2004.

[8] S. Rakić, S. Petrović, J. Kukić et al., "Influence of thermal treatment on phenolic compounds and antioxidant properties of oak acorns from Serbia," Food Chemistry, vol. 104, no. 2, pp. 830-834, 2007.

[9] S. Rakić, D. Povrenović, V. Tešević, M. Simić, and R. Maletić, "Oak acorn, polyphenols and antioxidant activity in functional food," Journal of Food Engineering, vol. 74, no. 3, pp. 416-423, 2006.

[10] E. Pallenbach, E. Scholz, M. König, and H. Rimpler, "Proanthocyanidins from Quercus petraea bark," Planta Medica, vol. 59, no. 3, pp. 264-268, 1993.

[11] Z. A. Kuliev, A. D. Vdovin, N. D. Abdullaev, A. B. Makhmatkulov, and V. M. Malikov, "Study of the catechins and proanthocyanidins of Quercus robur," Chemistry of Natural Compounds, vol. 33, no. 6, pp. 642-652, 1997.

[12] K. B. Pandey and S. I. Rizvi, "Plant polyphenols as dietary antioxidants in human health and disease," Oxidative Medicine and Cellular Longevity, vol. 2, no. 5, pp. 270-278, 2009.

[13] Y. Cai, Q. Luo, M. Sun, and H. Corke, "Antioxidant activity and phenolic compounds of 112 traditional Chinese medicinal plants associated with anticancer," Life Sciences, vol. 74, no. 17, pp. 2157-2184, 2004.

[14] J. J. Kim, B. K. Ghimire, H. C. Shin et al., "Comparison of phenolic compounds content in indeciduous Quercus species," Journal of Medicinal Plants Research, vol. 6, no. 39, pp. 52285239, 2012.

[15] R. Brossa, I. Casals, M. Pintó-Marijuan, and I. Fleck, "Leaf flavonoid content in Quercus ilex L. resprouts and its seasonal variation," Trees, vol. 23, no. 2, pp. 401-408, 2009.

[16] A. Kamalak, O. Canbolat, O. Ozay, and S. Aktas, "Nutritive value of oak (Quercus spp.) leaves," Small Ruminant Research, vol. 53, no. 1-2, pp. 161-165, 2004.

[17] H. P. S. Makkar, R. K. Dawra, and B. Singh, "Tannin levels in leaves of some oak species at different stages of maturity," Journal of Science of Food and Agriculture, vol. 54, no. 4, pp. 513$519,1991$. 
[18] S. Andrenšek, B. Simonovska, I. Vovk, P. Fyhrquist, H. Vuorela, and P. Vuorela, "Antimicrobial and antioxidative enrichment of oak (Quercus robur) bark by rotation planar extraction using ExtraChrom," International Journal of Food Microbiology, vol. 92, no. 2, pp. 181-187, 2004.

[19] T. B. Ng, F. Liu, and Z. T. Wang, "Antioxidative activity of natural products from plants," Life Sciences, vol. 66, no. 8, pp. 709-723, 2000.

[20] R. Paquin and P. Lechasseur, "Observations sur une méthode de dosage de la proline libre dans les extraits de plantes," Canadian Journal of Botany, vol. 57, no. 18, pp. 1851-1854, 1979.

[21] D. von Wettstein, "Chlorophyll-letale und der submikroskopische Formwechsel der Plastiden," Experimental Cell Research, vol. 12, no. 3, pp. 427-506, 1957.

[22] M. M. Bradford, "A rapid and sensitive method for the quantitation of microgram quantities of protein utilizing the principle of protein dye binding," Analytical Biochemistry, vol. 72, no. 1-2, pp. 248-254, 1976.

[23] A. Hagerman, I. Harvey-Mueller, and H. P. S. Makker, Quantification of Tannins in the Foliage-A Laboratory Manual, FAO/IAEA, Vienna, Austria, 2000.

[24] K. R. Markham, "Flavones, flavonols and their glycosides," in Methods in Plant Biochemistry, P. M. Dey and J. B. Harborne, Eds., Academic Press, London, UK, 1989.

[25] I. F. F. Benzie and J. J. Strain, "Ferric reducing/antioxidant power assay: direct measure of total antioxidant activity of biological fluids and modified version for simultaneous measurement of total antioxidant power and ascorbic acid concentration," Methods in Enzymology, vol. 299, pp. 15-27, 1998.

[26] S. I. Cacig and M. I. Szabo, "Spectrophotometric method for the study of the antioxidant activity applied on Ziziphus jujoba and Hydrangea paniculata aqueous extracts," in Zbornik Matice srpske za prirodne nauke (Proceedings for Natural Sciences), pp. 87-93, Matica Srpska, Novi Sad, Serbia, 2006.

[27] J. C. Espín, C. Soler-Rivas, and H. J. Wichers, "Characterization of the total free radical scavenger capacity of vegetable oils and oil fractions using 2,2-diphenyl-1-picrylhydrazyl radical," Journal of Agricultural and Food Chemistry, vol. 48, no. 3, pp. 648-656, 2000.

[28] W. Brand-Williams, M. E. Cuvelier, and C. Berset, "Use of a free radical method to evaluate antioxidant activity," LWT-Food Science and Technology, vol. 28, no. 1, pp. 25-30, 1995.

[29] L. C. Green, D. A. Wagner, J. Glogowski, P. L. Skipper, J. S. Wishnok, and S. R. Tannenbaum, "Analysis of nitrate, nitrite, and $[15 \mathrm{~N}]$ nitrate in biological fluids," Analytical Biochemistry, vol. 126, no. 1, pp. 131-138, 1982.

[30] N. Dasgupta and B. De, "Antioxidant activity of Piper betle L. leaf extract in vitro," Food Chemistry, vol. 88, no. 2, pp. 219-224, 2004.

[31] M. J. Davies, "The oxidative environment and protein damage," Biochimica et Biophysica Acta, vol. 1703, no. 2, pp. 93-109, 2005.

[32] M. Kemp, Y. M. Go, and D. P. Jones, "Nonequilibrium thermodynamics of thiol/disulfide redox systems: a perspective on redox systems biology," Free Radical Biology and Medicine, vol. 44, no. 6, pp. 921-937, 2008.

[33] O. V. Bulda, V. V. Rassadina, H. N. Alekseichuk, and N. A. Laman, "Spectrophotometric measurement of carotenes, xanthophylls, and chlorophylls in extracts from plant seeds," Russian Journal of Plant Physiology, vol. 55, no. 4, pp. 544-551, 2008.

[34] P. P. Saradhi, A. Alia, S. Arora, and K. V. S. K. Prasad, "Proline accumulates in plants exposed to UV radiation and protects them against UV induced peroxidation," Biochemical and Biophysical Research Communications, vol. 209, no. 1, pp. $1-5,1995$.

[35] N. Krishnan, M. B. Dickman, and D. F. Becker, "Proline modulates the intracellular redox environment and protects mammalian cells against oxidative stress," Free Radical Biology and Medicine, vol. 44, no. 4, pp. 671-681, 2008.

[36] C. R. Stewart, "Proline accumulation: biochemical aspects," in Physiology and Biochemistry of Drought Resistance in Plants, L. G. Paleg and D. Aspinall, Eds., pp. 243-251, 1981.

[37] A. Maggio, S. Miyazaki, P. Veronese et al., "Does proline accumulation play an active role in stress-induced growth reduction?" Plant Journal, vol. 31, no. 6, pp. 699-712, 2002.

[38] S. Rakić, R. Maletić, M. Perunović, and G. Svrzić, "Influence of thermal treatment on tannin content and antioxidation effect of oak acorn Quercus cerris extract," Journal of Agricultural Sciences, vol. 49, pp. 97-106, 2004.

[39] J. I. Kim, H. Y. Kim, S. G. Kim, K. T. Lee, I. H. Ham, and W. K. Whang, "Antioxidant compounds from Quercus salicina Blume stem," Archives of Pharmacal Research, vol. 31, no. 3, pp. 274-278, 2008.

[40] J. P. Salminen, T. Roslin, M. Karonen, J. Sinkkonen, K. Pihlaja, and P. Pulkkinen, "Seasonal variation in the content of hydrolyzable tannins, flavonoid glycosides, and proanthocyanidins in oak leaves," Journal of Chemical Ecology, vol. 30, no. 9, pp. 1693-1711, 2004.

[41] S. Maqsood and S. Benjakul, "Comparative studies of four different phenolic compounds on in vitro antioxidative activity and the preventive effect on lipid oxidation of fish oil emulsion and fish mince," Food Chemistry, vol. 119, no. 1, pp. 123-132, 2010.

[42] R. L. Prior, X. Wu, and K. Schaich, "Standardized methods for the determination of antioxidant capacity and phenolics in foods and dietary supplements," Journal of Agricultural and Food Chemistry, vol. 53, no. 10, pp. 4290-4302, 2005.

[43] D. Ŝtajner, B. M. Popović, J. Ĉanadanović-Brunet, and G. Anaĉkov, "Exploring Equisetum arvense L., Equisetum ramosissimum L. and Equisetum telmateia L. as sources of natural antioxidants," Phytotherapy Research, vol. 23, no. 4, pp. 546-550, 2009.

[44] D. Štajner, B. M. Popović, A. Kapor, P. Boža, and M. Štajner, "Antioxidant and scavenging capacity of Anacamptis pyrimidalis L.-Pyrimidal orchid from Vojvodina," Phytotherapy Research, vol. 24, no. 5, pp. 759-763, 2010.

[45] D. Štajner, B. M. Popović, D. Ćalić-Dragosavac, Đ. Malenčić, and S. Zdravković-Korać, "Comparative study on Allium schoenoprasum cultivated plant and Allium schoenoprasum tissue culture organs antioxidant status," Phytotherapy Research, vol. 25, no. 11, pp. 1618-1622, 2011.

[46] B. M. Popović, D. Štajner, K. Slavko, and B. Sandra, "Antioxidant capacity of cornelian cherry (Cornus mas L.)-comparison between permanganate reducing antioxidant capacity and other antioxidant methods," Food Chemistry, vol. 134, no. 2, pp. 734741, 2012.

[47] E. R. Sindhu, K. C. Preethi, and R. Kuttan, "Antioxidant activity of carotenoid lutein in vitro and in vivo," Indian Journal of Experimental Biology, vol. 48, no. 8, pp. 843-848, 2010.

[48] M. J. Rivas-Arreola, N. E. Rocha-Guzmán, J. A. Gallegos-Infante et al., "Antioxidant activity of oak (Quercus) leaves infusions against free radicals and their cardioprotective potential," Pakistan Journal of Biological Sciences, vol. 13, no. 11, pp. 537-545, 2010. 

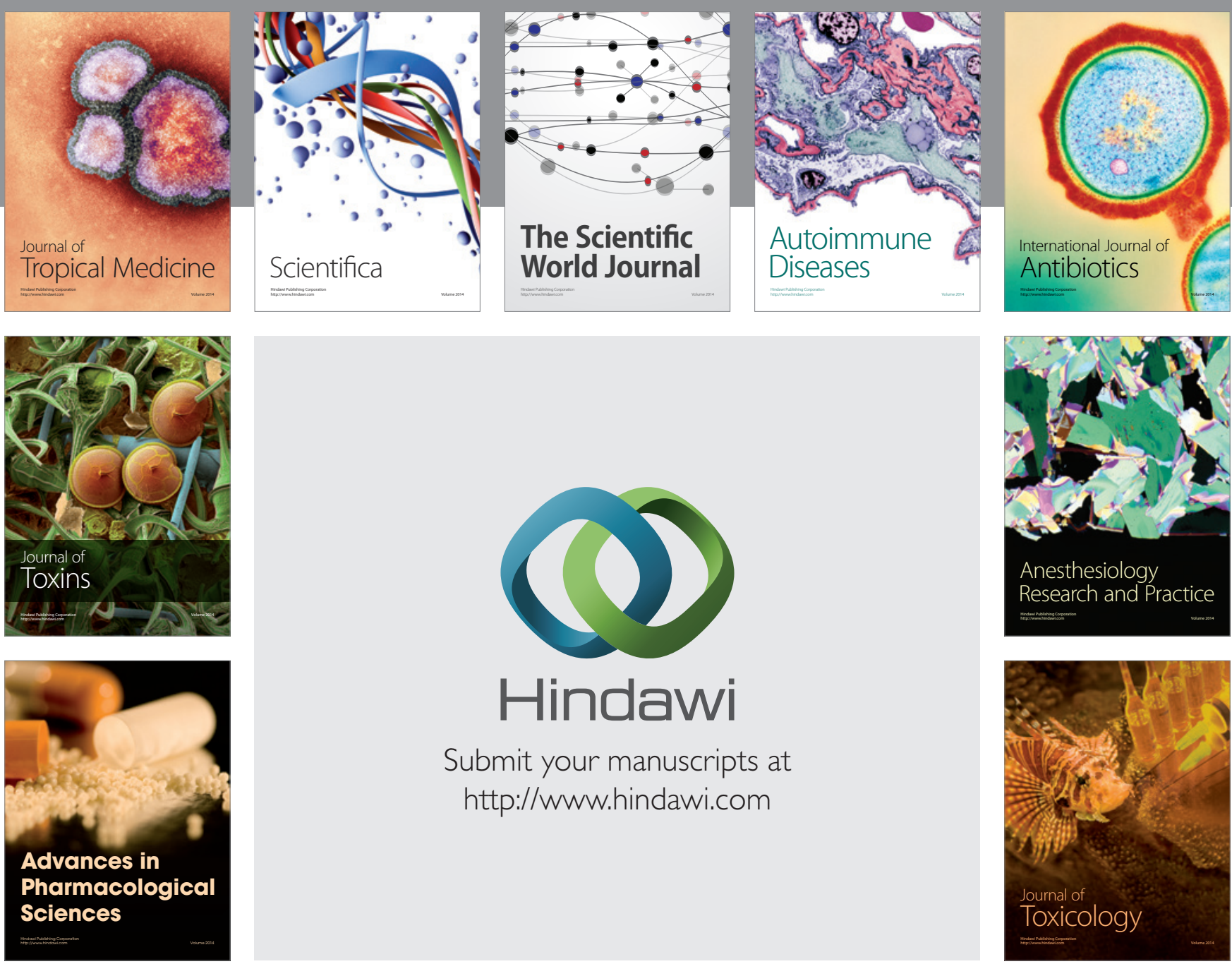

\section{Hindawi}

Submit your manuscripts at

http://www.hindawi.com
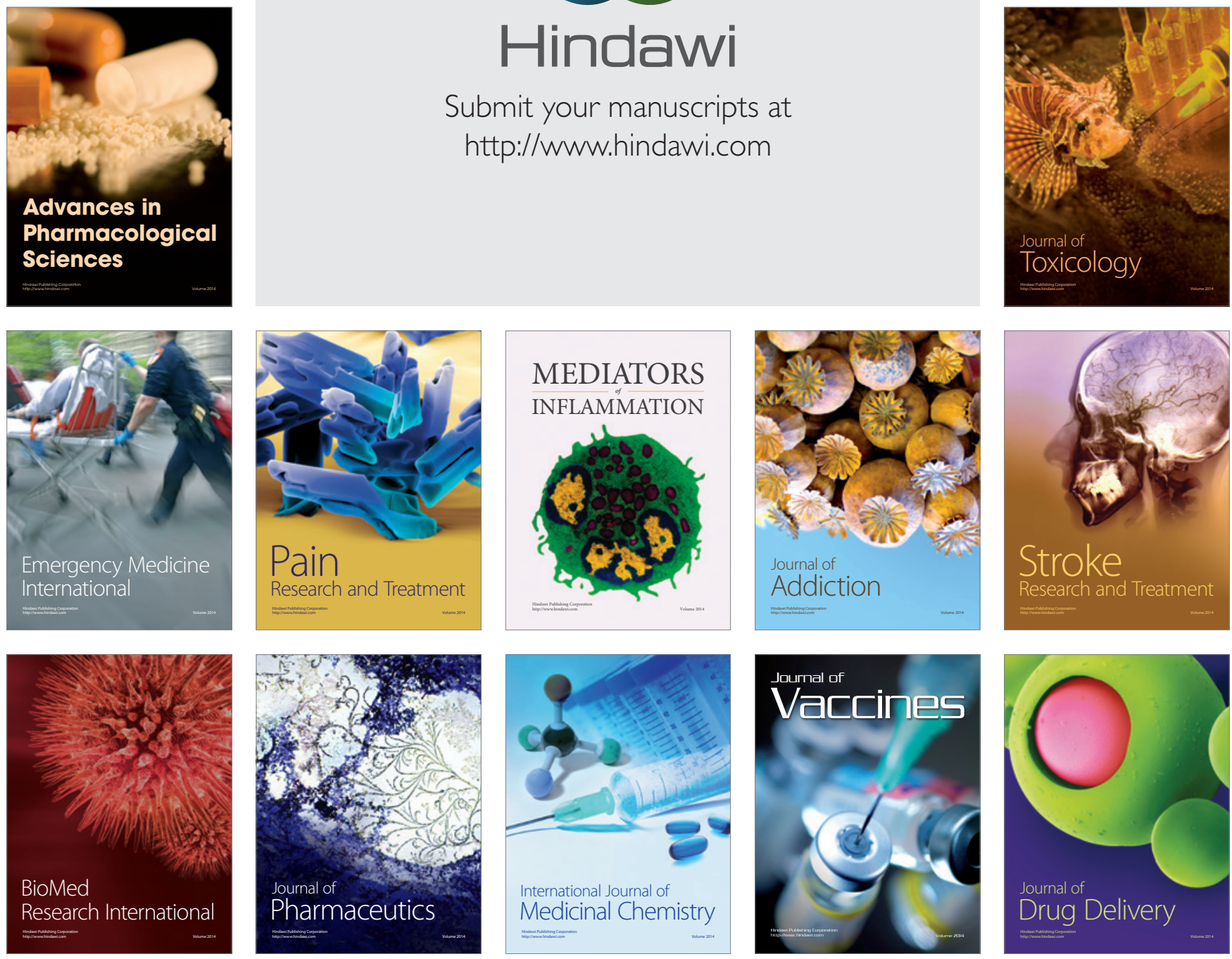